\title{
Management Options for Mitigating Natural Resource Training Impacts on Army Installations
}

by

David J. Tazik

Victor E. Diersing

Steven D. Warren

Calvin F. Bagley

Robert B. Shaw

As land uses and the condition of natural resources change, military natural resource managers are constantly confronted with new land management problems. They spend considerable time and resources trying to identify ways to minimize military impacts to soil and vegetation. This report serves as a checklist of management actions that can streamline the decision-making process and increase the likelihood that managers will consider the full range of alternative actions. 
The contents of this report are not to be used for advertising, publication, or promotional purposes. Citation of trade names does not constitute an official indorsement or approval of the use of such commercial products. The findings of this report are not to be construed as an official Department of the Army position, unless so designated by other authorized documents. 


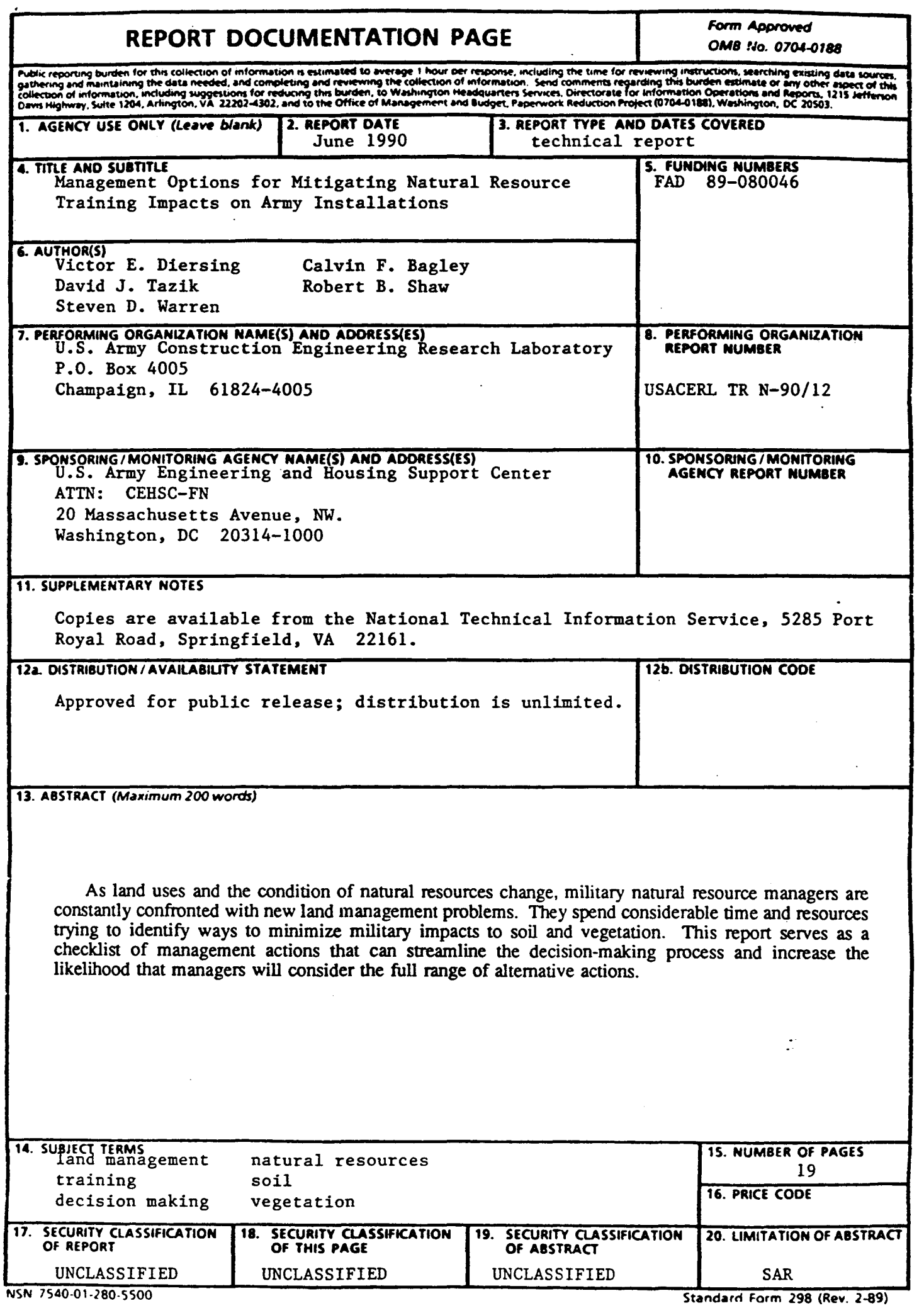




\section{FOREWORD}

This study was conducted for the U.S. Army Engineering and Housing Support Center (USAEHSC), under Project FAD No. 89-080046, "Land Condition-Trend Analysis." The USAEHSC Technical Monitor was Mr. Donald M. Bandel, CEHSC-FN.

This research was performed by the Environmental Division (EN) of the U.S. Army Construction Engineering Research Laboratory (USACERL). Dr. R. K. Jain is Chief of USACERL-EN. The USACERL technical editor was D.P. Mann, Information Management Office.

LTC E.J. Grabert, Jr. is Commander of USACERL and Dr. L.R. Shaffer is Director. 


\section{CONTENTS}

Background

Objective

Approach

Scope

Mode of Technology Transfer

2

MANAGEMENT TECHNIQUES

Limit Total Installation Use

Redistribution of Use

Modify Allowable Kinds of Uses

Alter Behavior Usage

Manipulate Natural Resources To

Improve Durability

3

SUMMARY AND RECOMMENDATIONS

15

REFERENCES

DISTRIBUTION 
MANAGEMENT OPTIONS FOR MITIGATING

NATURAL RESOURCE TRAINING

IMPACTS ON ARMY INSTALLATIONS

\section{INTRODUCTION}

Background

Army natural resource managers must maintain the natural resources in such a condition that opportunities for military training are not reduced and environmental laws are not violated." However, as pressures increase for more frequent and more intense training activity, these managers must continually try to identify ways to mitigate the resulting impacts to the natural resources. Currently, natural resource managers do not have information to help them identify alternative management actions. Generic procedures are needed to reduce the total time required in the decision-making process and to serve as a reminder of altemative actions that can be considered.

Objective

The objective of this report is to support the military training mission by outlining altemative actions for natural resource managers to use in mitigating natural resource impacts (primarily soil and vegetation damage) caused by military training activities.

\section{Approach}

The framework presented here for mitigating military training impacts is largely a synthesis of numerous discussions with Army natural resource managers over the past 7 years.

Scope

The scope of this report is limited to the mitigation of military training impacts to soil and vegetation resources. It does not include measures for mitigating impacts from other land uses such as timber production, grazing, or crop production.

Mode of Technology Transfer

This report is being transmitted to military natural resource managers.

\footnotetext{
- Army Regulation (AR) 420-74. Natural Resources.-Land, Forest, and Wildlife Management (Headquarters, Deparment of the Army [HQDA], 25 March 1986); AR 200-1, Environmental Quality, Environmental Protection and Enhancement (HQDA, 15 June 1982).
} 


\section{MANAGEMENT TECHNIQUES}

In general, physical impacts to an installation's natural resources can be minimized by one of five management techniques:

- limit total use,

- redistribute use,

- modify kinds of uses,

- alter the behavior of use, and

- manipulate the natural resources for increased durability.

These management techniques are outlined and discussed on the following pages and summarized in Table 1.

\section{Limit Total Installation Use}

This management action requires a reduction in total installation activity. It does not redistribute use or modify the kinds of uses on the installation. The five major methods for reducing total use at an installation are listed below.

\section{Limit Total Number of Users}

This method reduces the size or number of units that are allowed to train at a given installation. The action is seldom necessary unless degradation is widespread and chronic across the installation. In many cases overutilization of land can be mitigated by other management actions.

\section{Limit Total Days of Use}

This involves limiting the stay of user groups. For example, a battalion commander may have to reduce each field training mission from 21 days to 19 days.

\section{Lease or Purchase Additional Land Near Installation}

If total use on the installation appears to exceed the carrying capacity of the land, the land manager should recommend and encourage unit commanders and trainers to lease or purchase adjacent land for military training activities. Caution must be used to ensure that the lands to be acquired are suitable for the intended uses.

\section{Transfer a Portion of Total Activity to Other Installations}

If other installations (including other DOD, reserve, and National Guard installations) are underutilized, a portion of the total activity on the overutilized installation should be transferred. 
Table 1

Checklist for Minimizing Physical Impacts

1. Limit Total Use on Installation

a. Limit Total Number of Users

b. Limit Total Days of Use

c. Lease or Purchase Additional Land Near Installation

d. Transfer a Portion of Total Activity to Other Installations

e. Secure Suitable Land for a New Installation

2. Redistribute Use

a. Seasonal Redistribution

(1) Decrease Activity on Wet Soils

(2) Decrease Activity on Unfrozen Soils

(3) Reduce Time-Frame for Replacement of Vegetative Cover

b. Spatial Redistribution

(1) Decrease Use of Overutilized Areas

- Establish a Closure Policy

- Increase Restrictions

- Limit Access

- Decrease Desirability

(2) Increase Use of Underutilized Areas

- Establish a Required Use Policy

- Decrease Restrictions

- Improve Access

- Increase Desirability

3. Modify Allowable Kinds of Uses

a. Tracked/Wheeled Vehicle Use

b. Cutting of Woody Plants for Camouflage

c. Digging in Soil

d. Training on Wet Soils

e. Training During Period of High Fire Hazard

f. Training on Unfrozen Soils

4. Alter Behavior Usage

a. Teach to Protect

b. Regulate to Protect

5. Manipulate Natural Resources to Improve Durability
a. Buming
b. Mechanical
c. Biological
d. Chemical 
If all Army lands are fully utilized then new lands should be identified and a new installation established.

\section{Redistribution of Use}

The redistribution of use on an installation does not change the total amount of use nor the kinds of uses the land is receiving. The objective of redistribution is to reduce overutilization of some land areas and underutilization of others. The two basic methods of redistribution are seasonal and spatial. In some instances, such as rotational programs, time of use and location of use are interrelated. The selection of an appropriate land management decision should be based on an accurate quantitative description of the kinds, amounts, and conditions of the natural resources at the installation. The U.S. Army Land Condition-Trend Analysis (LCTA) program is designed to provide the needed information ${ }^{1}$. Using this information, methods have been developed to estimate the current condition and allowable use of military land by tracked vehicles.

\section{Seasonal Redistribution of Use}

Seasonal redistribution modifies the time of land use. It involves decreasing use when training activities have a high potential of impact and increasing use during other times. Trainers and unit commanders should be aware that unnecessary use of land during periods of high impact reduces its ability to support future mission activities. Examples of mitigation procedures follow:

Decrease Activity on Wet Soils. Military use of land during periods of high soil moisture significantly increases the likelihood of environmental damage. Soil water acts as a lubricant between soil particles. As pressure is applied, smaller particles are pressed between larger particles, increasing soil density and decreasing the amount of pore space for air. The net effect is a decrease in water infiltration, increased water runoff and erosion, reduced soil moisture, and a decline in plant growth. Graphs showing the "Probability of Weekly Precipitation" can be prepared for land managers who need to identify the likelihood of precipitation on a weekly basis at their installation ${ }^{2}$. With this information in hand, trainers and unit commanders can avoid scheduling major, heavy maneuvers or other intensive forms of land use when precipitation is likely. It is recognized that in some instances the military mission may require activity during wet conditions. However, repeated, unnecessary activity on wet soils should be avoided.

Decrease Activity on Unfrozen Soils. In the northem sections of the United States soils often freeze in the winter, particularly during late December, January, and early February. Well-frozen soils can often support the weight of tracked and wheeled vehicles without compaction and little damage to the soil surface. In comparison, training on unfrozen soils, particularly when they are wet, may result in deep ruts in the soil. Climate Diagrams which show the approximate time of the year that soils are frozen, are available for most northem installations ${ }^{3}$.

Reduce Time-Frame for Replacement of Vegetative Cover. In many regions soils never freeze during the fall and winter, and there is little change in soil moisture throughout the nongrowing season. Training activities at any time during this period cause about the same amount of damage. However, if impacts occur early in the nongrowing season, the soil may be left bare and subject to erosion for a long period

\footnotetext{
' V. E. Diersing, S. D. Warten, D. J. Tazik, R. B. Shaw, and R. J. Brozka, U.S. Army Land Condition-Trend Analysis (LCTA) Field Methods, Draft Report (USACERL, 1990).

${ }^{2}$ D. J. Tazik, V. E. Diersing, J. A. Courson, S. D. Warren, R. B. Shaw, and E. W. Novak, A Climatic Basis for Planning Military Training Operations and Land Maintenance Activities, Technical Report N-90/13 (USACERL, 1990).

${ }^{3}$ D. J. Tazik, V. E. Diersing, J. A. Courson, S. D. Warren, R. B. Shaw, and E. W. Novak.
} 
of time. On the other hand, if heavy maneuver exercises are delayed until late winter, the time required for replacement of vegetation cover is shortened, thus reducing the potential for erosion.

\section{Spatial Redistribution of Use}

The basic objective of spatial redistribution is to find altemative sites for a land use. It consists of two major actions: (1) decreased use of an overutilized area, and (2) increased use of an underutilized area. A method has been developed for classifying lands relative to their ability to support military impacts without exceeding soil loss tolerances".

Decrease Use of Overutilized Areas.

- Establish a closure policy. This eliminates all use of a particular area, usually a training area, or an area having a certain soil series or vegetation cover type. Based on the condition of the resources or the amount of prior use, a closure can range from permanent to short-term.

- Increase restrictions. These restrictions affect the locations of allowable uses within a large continuous area of land (training area, soil series, or vegetation cover type). Actions could be no off-trail travel, no tracked vehicles within 100 meters of riparian areas, or any other action that can modify location of use.

- Limit access. Whereas the above two techniques reflect changes in policy, this method does not. Some training lands receive too much use because of their proximity to the cantonment area, or because of a preferred mix of woodland and prairie cover. Access can be decreased by posting signs, hauling large dead trees onto overutilized trails, or placing large boulders along the sides of roads and trails which lead into or pass through these areas.

- Decrease desirability. This action is similar to the one above, but materials are not gathered to obstruct use, rather the natural resources are manipulated to reduce use. For example, a favorite bivouac site, which has had its understory obliterated through years of use, may not be as desirable if trees and shrubs are planted in the understory. As another example, the soil can be mechanically pitted (roughened) to reduce the desirability for use by wheeled vehicles.

\section{Increase Use of Underutilized Areas.}

- Establish a required use policy. "Required use" does not imply that an area must be used all the time. It simply means that if an area is underutilized, use should be increased instead of overutilizing another area. An area is usually underutilized because it is not desirable, which means the land must be improved before a "required use" policy can become effective.

- Decrease restrictions. Restrictions affect the location of allowable military training uses within a large continuous area of land. Examples of decreased restrictions may be to allow digging, cutting of vegetation for camouflage, off-trail use by tracked and wheeled vehicles, or the use of fire or river crossing sites.

- Improve access. Access to a site may be increased by building new roads or improving existing roads. In other instances, it may be necessary to build a bridge or fill a gully.

- Increase Desirability. A site may not be used because trees are too dense. If so, trees should be selectively thinned. Sometimes a site may not be used because of a lack concealment. In this case,

\footnotetext{
4 S. D. Warren, V. E. Diersing, P. J. Thompson, and W. D. Goran, "An Erosion-based Land Classification System for Military Installations," Environmensal Management, Vol 13. No. 2 (1989). pp 251-275.
} 
trees and shrubs should be planted. If trees occur in isolated clusters, they could be transplanted in a spacially desirable pattern. In large, open, flat areas, berms can be built to improve desirability.

\section{Modify Allowable Kinds of Uses}

This management action limits the allowable kinds of uses on the installation as a whole or more typically restricts the allowable kinds of uses on a site (usually a training area, plant community, or soil series). It does not involve finding an altemative site for an activity and thus it may only indirectly affect the spatial redistribution of use.

\section{Tracked/Wheeled Vehicle Use}

Tracked and wheeled vehicle training is an intensive form of land use, and some sites--either because of their slope, nature of the soils, amount of precipitation, or kind of vegetation--can support little of this activity. Other sites may be extremely durable. Based on measured changes in the status of natural resources, the land manager should advise on the amounts of use that different sites receive. A method has been developed for estimating sustainable levels of tracked vehicle use on nonwooded military training lands.

\section{Cutting of Woody Plants for Camouflage}

On some semi-arid or arid installations, trees may require several hundred years to grow more than 6 meters in height ${ }^{6}$. In more humid areas, certain species of trees may be relatively rare. To ensure the long-term availability of live, standing camouflage it may be necessary to curtail or eliminate the cutting of some or all woody plants.

\section{Digging in Soil}

Digging anti-tank ditches, hull-down positions, and fox holes; building berms; and practicing demolition are intensive forms of land use. Sites that continually support this type of activity must have deep, productive, low to moderately erodible soils. Activities conducted extensively on shallow soils, steep sites, or otherwise unsuitable areas, should be reduced or eliminated to maintain the site's stability.

\section{Training on Wet Soils}

A land manager can significantly reduce heavy mechanized use on wet soils by seasonal redistribution of use (previously discussed). Occasionally, however, soils may become extremely wet immediately after a summer thunderstorm at a time when they are otherwise usually relatively dry. In these circumstances, the land manager should have a given number of "wet days" per year where he/she has the authority to temporarily postpone training activities until the soils stabilize.

\section{Training During Period of High Fire Hazard}

Some installations receive little rain during the summer. Consequently the vegetation is dry and if adequate fuel is present, fires are highly likely. To avoid extensive bums, training activities that are more likely to cause wild fires should be scheduled for moister periods of the year.

\footnotetext{
5 V. E. Diersing, R. B. Shaw, S. D. Warren, and E. W. Novak, "A User's Guide for Estimating Allowable Use of Tracked Vehicles on Nonwooded Military Training Lands," Journal of Soil and Water Conservation, Vol 43, No. 2 (1988), pp 191-195. - V. E. Diersing. D. J. Tazik, and E. W. Novak, Growth Rate of Pinyon Pine (Pinus edulis) on Fort Carson and Pinon Canyon Maneuver Site, Colorado, Technical Report N-87/20/ADA183018 (USACERL, 19872), pp 1-33.
} 
As in training on wet soils, a land manager can minimize mechanized traffic on unfrozen soils by proper seasonal distribution of use, as discussed previously. Sometimes, though, unusually warm weather may cause the soil surface to thaw during a period when the soil is normally frozen. In these circumstances, the installation should allow for several days per year when training is postponed temporarily until the soils refreeze.

\section{Alter Behavior Usage}

Two basic methods can be employed to change the behavior of those who use the land. Attitudes can often be changed by teaching principles of wise land management, which in tum is reflected in how the land is used. Or, stricter regulations can be imposed, which may not affect attitudes, but which nonetheless results in changes in land use.

\section{Teach to Protect}

To ensure that quality training lands are available in the future each soldier must develop a concem for the training land beyond his or her tour of duty. Before using training lands, soldiers should be required to attend environmental awareness programs. The objective of these programs is to create a "land ethic." They should stress that the sustained availability of the training lands is the management goal and that degradation of the natural resources results in degradation of the training mission?

\section{Regulate to Protect}

It should be recognized that training lands are the Army's classroom and that unnecessary damage to the land affects the quality of the training experience for those who follow. Natural resource managers and military trainers should, in concert, fine those who unnecessarily destroy the training land resources. Monies collected through fines should be used to repair the damaged training lands.

\section{Manipulate Natural Resources To Improve Durability}

Training lands severely damaged by military training activities usually require many years to recover naturally. Man-assisted restoration can greatly speed up this process. Four primary land restoration techniques are available separately or in combination.

\section{Burning}

Judicious use of prescribed buming can increase the durability of training lands by manipulating the vegetation into a type better suited to withstand the impacts of training, or to speed the restoration of damaged training lands. Prescribed buming on training lands can generally be expected to accomplish one or more of the following results:

1. Kill or suppress undesirable nonsprouting shrubs.

2. Eliminate or prevent invasion of inferior species into the understory.

3. Selectively kill or reduce noxious weeds.

4. Rejuvenate sprouting shrubs.

\footnotetext{
' W. D. Severinghaus, "The Environment: A Tactical Advantage," Army Trainer, Fall, Vol 87 (1987), pp 34-35.
} 
5. Open up the understory for grasses and forbs.

6. Remove heavy or thick litter accumulation that prevents herbaceous plant growth.

7. Facilitate the movement of men and equipment.

8. Prepare seedbed for seeding of more desirable species.

9. Prepare ash seedbed for natural reproduction of desirable trees in a silvicultural program.

10. Reduce stagnation in dense forest stands by thinning.

11. Reduce the incidence of insect or fungal outbreaks.

Within the prescription for buming, care must be taken to properly assess fuel load, season of bum, frequency of burning and species composition. Other concerns are wind speed and direction, fire break width and down range pollution from smoke or wind-bome ash. Short-term effects on military concealment resources and a potential for increased erosion must also be addressed.

Mechanical

Mechanical methods are used to control trees and shrubs, to break up compacted soils, to control overland run-off and to prepare an appropriate seedbed for revegetation efforts. When used to control woody plants which sprout, mechanical methods may require follow-up procedures such as buming, herbicides, or browsing to ensure successful results. Selective opening of forested areas with mechanical methods can provide travel corridors to direct use to more durable areas. In some cases removal of a mature canopy can promote suckering and sprouting, providing more effective concealment cover. Improving the durability of compacted soil requires mechanical scarification and aeration in preparation for revegetation techniques. Other mechanical soil management treatments include contour furrowing, terracing, trenching, pitting, and ripping. These techniques are used to intercept and divert run-off, and to break up a hardened soil surface to allow greater infiltration and better plant growth. The best method depends on several factors:

1. Density, size, and growth form of the plant species to be controlled.

2. Characteristics of the species being replanted or reseeded.

3. Topography--slope, aspect ${ }^{8}$.

4. Soil type--depth, rock content, erodibility.

5. Potential productivity of the site versus cost of improvement.

Many choices for mechanical control techniques and equipment exist. Three general types of equipment are available.

\footnotetext{
- E. G. Vachta and R. E. Riggins, Erosion Control Methods for Army Land Rehabilitation: Survey of Current Technology, Technical Report N-88/05/ADA197566 (USACERL, 1988), pp 1-64.
} 
1. Bulldozers--used with a blade for earth moving operations such as contouring or terracing, or for knocking down or uprooting woody plants, or to drag a chain, cable or bar along the soil surface to knock down and uproot trees and shrubs or to cover seeds that been broadcast on the soil surface?.

2. Brush busters--saws, blades, or ams that cut, chop, or shred trees or brush.

3. Plows--harrows, chisels, rippers, pitters, root plows, or disks that chum up the roots and surface vegetation, break up compacted soil or change flow of surface run-off.

\section{Biological}

Biological manipulation is another method to implement change in order to gain greater durability of an area. Shifting the plant community to more desirable species through revegetation can be a tool to meet the needs of the training mission. This can be achieved through:

1. Reseeding

2. Planting of seedlings.

Revegetation can occur naturally if an area is "rested" or competing unwanted species are suppressed. Several criteria must be evaluated before deciding to use natural revegetation, however. The decision must be based on the recovery time of the species, ability to control unwanted species, availability of mature seed-producing plants vigorous enough to produce abundant seed, and the cost of placing the land offlimits for an extended period.

When recovery time must be minimized, artificial revegetation can often be used in conjunction with mechanical methods to speed the recovery process. Seed broadcasters can be attached to tractors and bulldozers that spread the seed as they perform other land treatments. Seed can also be broadcast by hand or by helicopter or airplane before or after any mechanical treatment. Mechanical seed drills have an added advantage of ensuring that seeds are incorporated into the soil at a uniform depth. Specially made rangeland drills are available for use on rough, rocky terrain that ordinary agronomic equipment cannot handle. Revegetation using seedlings can also follow most mechanical manipulations. Seedling planting is much more labor intensive and costly, and often requires longer protection from most land uses. Site and species selection is important in the success of any revegetation effort. Not all sites can be successfully revegetated within budgetary constraints. Some important factors are:

1. Precipitation--amount and season. Seeding prior to a heavy rainfall period may mean seed is washed out to low lying areas or left unprotected by the soil and prone to predation by birds, insects, and small mammals. Cold wet weather may cause the seed to mold and rot, reducing germination. Insufficient moisture can prevent germination or cause death of young susceptible seedlings.

2. Temperature and wind. Frost, high temperatures and high wind velocities can desiccate young seedlings and uncover seed and new roots.

3. Choice of species. Native species should be the first choice in any revegation effort. Seed and seedlings should be from local sources grown under similar conditions and free from foreign contaminants.

\footnotetext{
' V. E. Diersing, B. R. Jones, S. D. Warren, and D. M. Herber, Juniper Chaining: A Vegetative and Soil Erosion Assessment of a methad of Rangeland Improvement on Fort Hood, Texas, Technical Repor N-87/05/ADA178114 (USACERL, 1987). pp. $1-40$.
} 
Some introduced species have excellent characteristics to improve the durability of the land. Seed mixes are recommended over monotypic seedings. This enhances ecological diversity and promotes greater environmental stability. Other factors in species selection include:

- Ease of establishment

- Drought resistance

- Response to fire or training activities

- Response to weed control and other treatments

- Stand maintenance requirements

- Growth characteristics--hizomes, tillering, sprouting, and natural seed protection

- Erosion control.

Chemical

Herbicides, insecticides, and fertilizer are helpful in changing or improving the vegetation component on training lands. The use of herbicides to control undesirable plants has several advantages over other control methods. Herbicides:

- Are less expensive than most mechanical methods (may be more expensive than fire).

- May be used where access by mechanical equipment is limited by rough or steep terrain.

- Are more selective in controlling of certain plant categories and more effective on sprouting species.

- Are less labor intensive.

- Can maintain a grass cover without the loss of lister and exposing the soil to erosion.

- Provide rapid plant response.

- Can affect large areas in a short time.

- Are safer than fire when applied with proper environmental concem.

When applying herbicides caution must be exercised in following label directions, preventing drift to neighboring croplands, and avoiding contamination of lakes and streams. Application should follow standard operating procedures and be administered by trained personnel to reduce any deleterious effects.

Insecticides can be used to reduce insect outbreaks that can be lethal to the vegetation. Grasshopper infestations can remove ground cover, increase erosion, prevent natural seed production, and aggravate drought related mortality. Forest insects can kill trees and increase fire danger. As with herbicides, caution should be exercised to avoid contamination of personnel, nontarget organisms and waterways.

Fertilizer application can aid in establishing new seedings and rejuvenating decadent stands of vegetation. Proper application procedures should include soil analysis to ensure proper nutrient application levels. Other factors to consider are soil moisture, nontarget species impact, weather pattems, and contamination of streams and lakes. 


\section{SUMMARY AND RECOMMENDATIONS}

This report summarizes management techniques that can be used to minimize military training impacts to the soil and vegetation resources (Table 1). The five basic management techniques are: (1) limit total use; (2) redistribute use; (3) modify kinds of uses; (4) alter the behavior of use; and (5) manipulate the natural resources for increased durability. Several altemative actions that can be taken for each of these techniques were outlined and discussed.

It is recommended that examples of how installations have managed specific problems be documented and made available to natural resource managers at other military installations.

\section{REFERENCES}

Diersing, V. E., D. J. Tazik, and E. W. Novak, Growth Rate of Pinyon Pine (Pinus edulis) on Fort Carson and Pinon Canyon Maneuver Site, Colorado, Technical Report N-87/20/ADA183018 (USACERL, 1987), pp 1-33.

Diersing, V. E., R. B. Shaw, S. D. Warren, and E. W. Novak, "A User's Guide for Estimating Allowable Use of Tracked Vehicles on Nonwooded Military Training Lands," Journal of Soil and Water Conservation, Vol 43, No. 2 (1988), pp 191-195.

Diersing, V. E., B. R. Jones, S. D. Warren, and D. M. Herbert, Juniper Chaining: A Vegetative and Soil Erosion Assessment of a Method of Rangeland Improvement on Fort Hood. Texas, Technical Report N-87/05/ ADA178114 (USACERL, 1987), pp 1.40.

Diersing, V. E., S. D. Warren, D. J. Tazik, R. B. Shaw, and R. J. Brozka, U.S. Army Land Condition-Trend Analysis (LCTA) Field Methods, Draft Report (USACERL, 1990).

Severinghaus, W. D., "The Environment: A Tactical Advantage," Army Trainer, Fall, Vol 87 (1987), pp 34-35.

Tazik, D. J., V. E. Diersing, J. A. Courson, S. D. Warren, R. B. Shaw, and E. W. Novak, A Climatic Basis for Planning Military Training Operations and Land Maintenance Activities, USACERL Technical Report N90/13 (USACERL, 1990).

Vachta, E. G., and R. E. Riggins, Erosion Control Methods for Army Training Land Rehabilitation: Survey of Current Technology, Technical Repon N-88/05/ADA197566 (USACERL, 1988), pp 1-64.

Warren, S. D., V. E. Diersing, P. J. Thompson, and W. D. Goran, "An Erosion-based Land Classification System for Military Installations," Environmental Management, Vol 13, No. 2 (1989), pp 251-257. 